\title{
Tietojärjestelmän käyttöönotto ja koulutus
}

\section{- kokemuksia Vantaan tuomiokunnasta}

Vartiainen, Matti ja Järvenpää, Eila. 1988. Tietojärjestelmän käyttöönotto ja koulutus - kokemuksia Vantaan tuomiokunnasta. Aikuiskasvatus 8, 3, 4-9. - Tietotekniikan soveltaminen toimistotöihin on ollut valtiohallinnon työpaikkojen näkyvimpiä uudistuksia koko 80-luvun lopun ajan. Artikkelissa käsitellään pitkittäistutkimuksen valossa tietojärjestelmän käyttöönoton organisointia ja annettua koulutusta Vantaan tuomiokunnassa. Käyttöönottoa seurattiin vuodesta 1985 alkaen, ja tutkimus jatkuu edelleen. Tietoja kerättiin havainnoinnein, haastatteluin ja kyselyin. Tutkijat osallistuivat myös annettuun koulutukseen. Käyttöönottovaihe venyi odotettua pitemmäksi ja tietotekniikka vaikutti aluksi vain muutamien ihmisten työn sisältöihin. Sovellusten kehittämisen myötä yhä useammasta tulee tietotekniikan käyttäjiä. Koulutuksen ajoittaminen osoittautui vaikeaksi. Koulutuksen keskeisimmiksi vaiheiksi osoittautuivat kehitystyön alku ja varsinainen tietojärjestelmän käyttöönottovaihe. Artikkelin lopuksi esitetään suositukset käyttöönotto-organisaatioksi ja koulutuksen sisällöksi.

\section{Johdanto}

Tietojärjestelmien käyttöönotto on viime vuosina ollut vilkkaan kiinnostuksen kohteena (esim. Korvajärvi \& Rantalaiho 1984, Kallioniemi 1985). Seuraavassa kuvataan ja arvioidaan pitkittäistutkimuksen valossa tietojärjestelmän käyttöönoton organisointia ja annettua koulutusta Vantaan tuomiokunnassa ja erityisesti sen kansliassa. Tietojärjestelmän suunnittelu ja käyttöönoton toteuttaminen nähdään prosessina, johon osallistumalla henkilöstö erittelee työtään sekä oppii kehittämään itseään ja työkokonaisuuksiaan. Osallistuva käyttöönotto ei siis ole vain keino voittaa ns. muutosvastarinta ja legitimoida ylempänä organisaatiossa asetettuja tavoitteita.

Työntekijöiden koulutuspohja ja tiedot atk:sta selvitettiin haastatteluilla ja kyselyillä ennen kehittämistyön alkua keväällä 1985. Tutkimukseen osallistui tuolloin koko tuomiokunnan henkilöstö $(\mathrm{N}=38)$. Kehittämisprojektin aikana tutkijat osallistuivat koulutuksen järjestämiseen. Keväällä 1987 toistettiin hankkeen alussa tehdyt kyselyt sekä arvioitiin muutosprojektin onnistumista. Käyttöönoton jälkeen tutkimukseen osallistuivat ne henkilöt, jotka olivat mukana jo alkukartoituksessa $(\mathrm{N}=26)$.
Seuraavassa esitellään tietojärjestelmän suunnittelun ja käyttöönoton kulku, sisältö ja nykyvaihe, henkilöstön koulutuspohja sekä toimistoautomaation aiheuttama koulutustarve ja toteutunut koulutus. Lopuksi arvioidaan tietojärjestelmän suunnittelun ja käyttöönoton organisointia ja annettua koulutusta sekä esitetään niitä koskevia suosituksia.

\section{Tietojärjestelmän suunnittelu ja käyttöönotto}

Oikeusministeriö asetti v. 1983 työryhmän selvittämään alioikeuksien tekstinkäsittelyn ja muun tietojenkäsittelyn kehittämistarpeet, oikeushallinnon tietojärjestelmien tietojenkäsittelytehtävien siirtämisen alioikeuksiin sekä alioikeuksien tietojenkäsittelyyn soveltuvat laitteistovaihtoehdot. Työryhmässä oli edustajia oikeusministeriöstä, alioikeuksista ja Valtion tietokonekeskuksesta (VTKK).

Työryhmä sai työnsä valmiiksi 1984, jolloin hanke jatkui Vantaan tuomiokunnan tietojenkäsittelyn kehittämisprojektissa ja alioikeuksien arkkitehtuurityöryhmässä. Työryhmät toimivat samanaikaisesti ja osittain yhteistyössä. Vantaalla tehtiin tietojenkäsittelyn kokonaistutkimus ja laadittiin tuomiokunnan tietojenkäsit- 
telyn kehittämissuunnitelma vuonna 1986 Suunnittelutyötä ohjasi johtoryhmä, jona toimi tuomiokunnan virastodemokratiaelin. Lisäksi oli projektiryhmä, johon kuuluivat kihlakunnan tuomari, käräjätuomari ja kaksi toimistosihteeriä tuomiokunnasta, edustaja oikeusministeriöstä sekä konsultti VTKK:sta. Suunnitteluryhmien työtä tuettiin perustamalla tuomareista, notaareista ja kansliahenkilökunnasta työkokonaisuuksittain muodostetut kehittämisryhmät. Ne kartoittivat työtehtäviä ja laativat ehdotuksia tietotekniikan soveltamisesta töihinsä. Projektiryhmä laati ehdotusten perusteella tietojenkäsittelyn kehittämissuunnitelmaluonnoksen, jota käsiteltiin työryhmissä marraskuussa 1985.

Arkkitehtuurityöryhmä laati ehdotuksen alioikeuksien toimistotietojärjestelmän arkkitehtuuriksi ja teki ehdotukset Vantaan tuomiokunnan atk-laitteista ja niiden hankinnoista. Työn ohjaajana oli oikeusministeriön ja VTKK:n koordinointiryhmä. Työryhmään kuului näiden lisäksi edustajia myös Vantaan tuomiokunnasta. Ehdotusten lähtökohtana olivat tuomiokun- nan tietojen käsittelytutkimus sekä Hämeenlinnan raastuvanoikeuden ja Hauhon tuomiokunnan kokemukset. Työryhmä tutustui myös ruotsalaisiin toimistotietokoneita koskeviin vaatimuksiin ja standardeihin (Ehdotus... 1986, 1).

\section{Tietojärjestelmän sisältö ja nykyvaihe}

Tuomiokuntaan tuli elokuussa 1986 kuusi IBM PC XT -mikrotietokonetta ja yksi IBM PC AT -mikrotietokone aiemmin siellä olleen päätteen lisäksi. Päätettä käytetään kiinteistötietojen syöttöön ja tulostukseen. Uudet laitteet tulivat käräjäkanslian neljälle konekirjoittajalle, kihlakunnantuomarin sihteerille sekä asuntooikeuden kanslianhoitajalle. Keväällä 1987 yksittäiset mikrot kytkettiin verkoksi. Taulukossa 1 esitellään hankitut tai suunnitteilla olevat tietojärjestelmät.

Taulukko 1. Tuomiokunnassa toteutetut ja toteutettavat tietojärjestelmät (Vantaan tuomiokunnan... 1986, 31-38) ja toteuttamistilanne syksyllä $1987 . \mathrm{A}=$ käytössä, $\mathrm{B}=$ suunnitteilla, C = keskitetty järjestelmä, $\mathrm{D}$ = paikallinen järjestelmä, $\mathrm{E}$ = valmis järjestelmä, $\mathrm{F}$ = itse kehitetty/itse kehitettävä.

\begin{tabular}{|c|c|c|c|c|c|c|}
\hline JÄRJESTELMÄT & A & B & $\mathrm{C}$ & $\mathrm{D}$ & E & $\mathrm{F}$ \\
\hline — kiinteistötietojärjestelmä (KTJ) & $x$ & - & $\mathrm{x}$ & - & $\mathrm{x}$ & - \\
\hline - rikosasiain tuomiolauselmaiärjestelmä (TLP) & $\hat{x}$ & - & $\hat{x}$ & - & $\hat{x}$ & - \\
\hline - päätösten valmistelun apu (FINLEX-tietopankki) & $\mathrm{x}$ & - & $\mathrm{x}$ & - & $\mathrm{x}$ & - \\
\hline - tekstinkäsittely (TEKO) & $\mathrm{x}$ & - & - & $\mathrm{x}$ & $\mathrm{x}$ & - \\
\hline — diaarijärjestelmä & - & $\mathrm{x}$ & - & $\mathrm{x}$ & - & $\mathrm{x}$ \\
\hline - perukirjarekisteri & - & $\mathrm{x}$ & - & $\mathrm{x}$ & $\mathrm{x}$ & - \\
\hline - asiakirjojen postitus, maksatus- & & & & & & \\
\hline ja kirjanpitojärjestelmä & - & $\mathrm{x}$ & - & $\mathrm{x}$ & $\mathrm{x}$ & $\mathrm{x}$ \\
\hline - maksamismääräysasioiden järjestelmä & - & $\mathrm{x}$ & $\mathrm{x}$ & - & - & $\mathrm{x}$ \\
\hline — holhousasioiden järjestelmä & - & $\mathrm{x}$ & $\mathrm{x}$ & - & - & $\mathrm{x}$ \\
\hline - muut tietojärjestelmät, esim. lomat, istuntolistat & - & $\mathrm{x}$ & - & $\mathrm{x}$ & $\mathrm{x}$ & - \\
\hline - elektroninen posti & $\mathrm{x}$ & - & $\mathrm{x}$ & $\mathrm{x}$ & $\mathrm{x}$ & - \\
\hline — yhteys väestörekisteriin & - & $\mathrm{x}$ & $\mathrm{x}$ & - & $\mathrm{x}$ & - \\
\hline - muut sidosryhmät (TJY, Vahorik.rek. yms) & - & $\mathrm{x}$ & $\mathrm{x}$ & - & $\mathrm{x}$ & - \\
\hline -- omat päätösten valmistelun apujärjestelmät (VANLEX) & - & $\mathrm{x}$ & - & $\mathrm{x}$ & - & $\mathrm{x}$ \\
\hline
\end{tabular}

Tuomiokunnan tietojärjestelmä voidaan esittää kolmetasoisena: työasemat, työasemat verkkoon kytkettynä ja työaseman yhteys verkon kautta keskitettyihin järjestelmiin.

Työasemat voivat toimia myös itsenäisesti. Verkon kautta voidaan käyttää yhteisiä tiedostoja, kuten diaari, Vanlex ja erilaiset valmiit tekstipohjat. Verkon kautta ollaan edelleen yhteydessä keskitettyihin järjestelmiin, esim. Finlex, ja hoidetaan tietoyhteydet esim. oikeusministeriöön.

\section{Koulutus}

\section{Henkilöstön koulutuspohja}

Vantaan tuomiokunnan työntekijöillä oli kehittämisprojektin alkaessa varsin hyvä peruskoulutus. Yli puolet työntekijöistä oli peruskoulutukseltaan ylioppilaita. 
Kihlakunnantuomarin ja käräjätuomarien $(\mathrm{N}=9)$ virkoihin vaaditaan oikeustieteen kandidaatin tutkinto ja suoritettu tuomioistuinharjoittelu. Notaarit $(\mathrm{N}=9)$ ovat oikeustieteen kandidaatteja, jotka suorittavat tuomioistuinharjoitteluaan varatuomarin arvon saamiseksi. Kansliahenkilökunnalla $(\mathrm{N}=17)$ ja vahtimestareilla $(\mathrm{N}=3)$ ei ole muodollisia pätevyysvaatimuksia.

Tuomareilla oli peruskoulutuksen ja auskultoinnin lisäksi vain vähän jatkokoulutusta, useimmiten päivän parin lisäkursseja. Yhdellä tuomareista oli myös hallinnollisia kursseja. Kahdella notaareista oli myös kaupallisen alan loppututkinto.

Kansliahenkilökunnasta vain neljällä ei ollut ammatillista koulutusta. Muut olivat käyneet esim. kauppakoulun tai -opiston ja yksivuotisen sihteerikurssin.

Valtaosalla työntekijöistä oli kokemuksia tai tietoja atk:n käytöstä jo ennen projektin alkua.

Tuomareilla oli kokemuksena esim. Finlex, Vantaan kiinteistörekisteri ja lainhuudot. Notaarien kokemus oli jonkin verran laajempi sisältäen edellä mainitun lisäksi mm. atk-peruskursseja ja tekstinkäsittelyä. Kansliahenkilökunnalla oli kokemuksia kiinteistörekisterin lisäksi mm. atk-tallennuksesta.

Suurin osa henkilöstöstä piti saamiaan toimistoautomaatiota koskevia tietoja riittämättöminä. Tyytyväisimpiä olivat notaarit. Lehdet, radio ja TV sekä työtoverit olivat selvästi yleisimmät toimistoautomaatiotiedon lähteet. Tärkeimmäksi tiedon lähteeksi mainittiin työtoverit.

\section{Toimistoautomaation aiheuttama koulutustarve}

Työkokonaisuudet, myös silloin kun ne toteutetaan tietotekniikan avulla, muodostuvat työtehtävistä. Ne voidaan jaotella työntekijöiltä edellytettyjen ajattelu- ja suunnitteluvaatimusten mukaan tasoihin. Perustason muodostavat erilaiset rutiinityötehtävät, esim. postitus ja kirjoittaminen. Tietotekniikan tullessa taloon konekirjoituksesta tulee tekstinkäsittelyä, mikä toteutetaan tekstinkäsittelyohjelmien avulla. Tämä luonnollisesti edellyttää koulutusta. Seuraavalla tasolla on yhden työkokonaisuuden, esim. käräjäkanslian, koko työnkulun ja siinä käytettävien työvälineiden hallinta. Vantaalle ja muihin tuomiokuntiin on suunnitteilla koko joukko (taulukko 1) erilaisia ohjelmistoja, joista osalla toteutetaan tietyn työkokonaisuuden tehtävät. Kolmannella tasolla on tuomiokunnan eri töiden koordinointi. Neljäntenä tasona voidaan pitää tuomiokunnan töiden ja työkalujen, esim. ohjelmat, kehittämistä ennalta määritellyllä tavalla. Viidentenä on tuomiokunnan töiden ja työkalujen kehittäminen ennalta mää- rittelemättömällä tavalla, asettamalla itse tavoite ja kehittämällä keinot sen saavuttamiseksi. Käytännössä tuomiokunnan vaatimukset ovat jopa neljännellä tasolla, esim. Vanlexin kehittäminen. Lainsäädäntö rajaa korkeamman tason kehittämisvaatimukset käytännössä pois.

Virtanen (1984) on ryhmiteilyt toimistoautomaation aiheuttamia ammattitaitovaatimuksia neljään pätevyysalueeseen:

- henkilökohtaisiin ominaisuuksiin liittyvät, esim. näppäryys ja tarkkuus

- toimistotyön perinteiset ammattitaidot, esim. konekirjoitus- ja kielitaito

- laitetekniset taidot, esim. laitteiden ominaisuuksien ja nappulatekniikan tuntemus

- automaation hallintaan liittyvät taidot, esim. atk-periaatteiden tuntemus.

Vantaan tuomiokunnassa kysyttiin henkilöstön käsityksiä toimistoautomaatiolaitteiden käytön vaatimista taidoista. Vastaukset ryhmiteltiin Virtasen esittämien pätevyysalueiden mukaisesti. Saaduissa vastauksissa painotettiin eniten henkilökohtaisia ominaisuuksia. Kansliahenkilökunta korosti lisäksi laiteteknisten taitojen merkitystä.

\section{Koulutussuunnitelma}

Alioikeuksien tietojenkäsittelytyöryhmän mietinnössä todettiin toimistoautomaation käyttöönoton vaativan laajaa koulutusta. Henkilöstön osallistumisen toiminnan kehittämiseen ja järjestelmien suunnitteluun arveltiin edistävän käytön oppimista. Suunnitelmassa tietotekniikan käyttöön katsottiin liittyvän kehittämis- ja käyttötehtäviä. Kehittämistehtäviä ovat mm. kehittämisen johto, ohjaus ja koordinointi, järjestelmien ja sovellutusten kehittäminen sekä laitteisto ja ohjelmistovastuu. Käyttötehtäviä ovat mm. tietojärjestelmien, ohjelmistojen ja työasemien käyttö.

Henkilöstön katsottiin tarvitsevan tietotekniikkakoulutusta seuraavilta osa-alueilta: yleiset perusvalmiudet, kehittämis- ja valmistelutehtävät sekä tietojärjestelmien käyttöönotto, käyttö, soveltaminen ja ylläpito. Koulutus suunniteltiin järjestettäväksi seuraavasti:

- Yleiskoulutuksen järjestävät yhteistyössä oikeusministeriö, tuomiokunta, valtionhallinnon kehittämiskeskus (VKK), VTKK ja muut koulutuksen tarjoajat.

- Tekstinkäsittelykoulutuksen järjestää järjestelmätoimittaja ohjattuna itseopiskeluna.

- Päätteen käyttökoulutus järjestetään samalla periaatteella. Yleisohjelmistojen osalta käytetään myös oikeusministeriön atk-palvelukeskuksen koulutuspalveluita. 
- Järjestelmäkohtainen koulutus tapahtuu pääosin työpaikkakohtaisena koulutuksena.

- Välitason tietokoneen (verkko) käyttökoulutus tapahtuu pääosin työpaikkakohtaisena koulutuksena.

- Kehittämiskoulutuksen järjestävät oikeusministeriön ja tuomiokunnan kehittämisvastuuhenkilöt VKK:n ja VTKK:n avustamana.

\section{Koulutuksen toteutuminen}

Tietotekniikan yleiskoulutus käynnistyi projektin alkuvaiheessa toukokuussa 1985. Yhden päivän luennoilla käsiteltiin työn organisoinnin kysymyksiä ja tietotekniikan soveltamista työelämässä. Luentojen jälkeen perustettiin työyhteisön tietojenkäsittelyn kehittämisryhmät, jotka analysoivat työtehtäviä ja laativat ratkaisuehdotuksia töiden tietokoneistamiseksi. Loppuvuodeksi 1985, kun oletettiin laitteiden tulevan muutaman kuukauden sisällä, työntekijöille järjestettiin vapaaehtoista itseopiskelua tietotekniikan perusteista. Luettavaksi annettiin kirja "Tietotekniikka, hallinto ja oikeus" (Stenlund ja Lampola 1985), jota käytiin läpi kirjeopiskelutyyppisesti. Tähän kertaukseen osallistui noin puolet työntekijöistä. Muutamat työntekijöistä menivät oma-aloitteisesti tietotekniikan kursseille.

Laitteiden tulon aikana syyskuussa 1986 ehdotettiin tutustumista ergonomisiin kysymyksiin ennen laitteiden sijoittamista työhuoneisiin. Tähän tarkoitukseen suositeltiin Työterveyslaitoksen julkaisua "Päätetyö" (Huuhtanen, Launis ja Lehtelä 1983).

Laitteiden tultua Valtion tietokonekeskuksen kouluttaja opasti yhden päivän ajan mikrotietokoneiden toimintaperiaatteita ja käyttöä. Häneltä ja laiteasentajilta konekirjoittajat saivat myös tekstinkäsittelyn opastusta.

Laitteisiin perehtyminen ja tekstinkäsittelyn opiskelu alkoivat itseopiskeluna. Työajan käyttöön kohdistuneen seurantapäiväkirjan palauttaneet (viisi käyttäjää kuudesta) harjoittelivat normaaleja pöytäkirjoja kirjoittamalla keskimäärin neljänä päivänä viikossa. Tämän jälkeen he ilmoittivat käyttäneensä mikrotietokonetta pöytäkirjojen, kirjeiden ja luetteloiden kirjoittamiseen. Jo muutaman päivän opetteluvaiheen jälkeen siis siirryttiin kokonaan uusien laitteiden käyttöön.

Varsinainen tekstinkäsittelykoulutus annettiin kahtena peräkkäisenä päivänä Valtion tietokonekeskuksen Teko-kurssilla. Kurssille osallistui seitsemän kansliahenkilökunnan jäsentä ja käräjätuomari, joka oli viraston tietojenkäsittelyn vastuuhenkilö.

Kurssilla käsiteltiin tekstinkäsittelyn kannalta tärkeitä mikrotietokoneen perustoimintoja, kuten levykkeiden alustamista ja tiedostojen kopiointia. Teko-tekstinkäsittelyohjelmasta opeteltiin perustoimintoja, esim. kirjoitus ja selaus, ja tehosteita, esim. alleviivaus ja lihavointi. Tiedostojen hallintaa ja hyödyntämistä, esim. hakua, poistoa ja luetteloiden käyttöä, neuvottiın myös jonkin verran (Pirhonen 1987).

\section{Tietotekniikkaa koskevan tiedontarpeen ja annetun koulutuksen vastaavuus}

Kahdeksantoista vastanneista ei ennen projektin alkamista esittänyt mitään tietotekniikkaa koskevan lisätiedon tarvetta. Kaksi henkilöä oli kiinnostunut saamaan lisätietoja toimistoautomaation vaikutuksista, esim. työtehtäviin tai henkilöstön määrään. Laitetekniikasta tai ohjelmoinnista oli kiinnostunut kolme. Sen sijaan yleistietoja, esim. mihin tietoja voidaan soveltaa, halusi viisitoista. Uusintakyselyssä v. 1987 vastaukset olivat pysyneet likimain samoina.

Ennen projektin alkua arviot käytön oppimiseen tarvittavan ajan pituudesta vaihtelivat yhdestä vuodesta pariin päivään. Valtaosa vastanneista arveli käytön oppimisen kestävän alle kuukauden. Uusintakyselyssä arviot oppimiseen tarvittavan ajan pituudesta olivat kasvaneet, niin että valtaosa arveli oppimiseen tarvittavan yli kuukauden.

\section{Arviointia ja johtopäätöksiä}

\section{Suunnittelun ja käyttöönoton organisointi}

Tuomiokunnan tietojärjestelmän suunnittelua tehtiin useissa työryhmissä. Toiminnan tavoitteet ja puitteet määriteltiin pitkälti oikeusministeriössä, esim. aikataulu, laitteet ja ohjelmistot. Käytännön toteuttamisessa käytettiin henkilökunnan apua aktiivisesti esim. kehittämisryhmien muodossa. Kehittämisryhmät eivät kuitenkaan käytännössä jatkaneet toimintaansa kehittämissuunnitelman valmistumisen jälkeen. Suhteellisen kankeaa ja hidassoutuista suunnittelukoneistoa voidaan perustella tarpeella tehdä varmoja ja luotettavia päätöksiä; olihan kysymys kaikkien alioikeuksien tietojenkäsittelyn kehittämisestä ja Vantaan tuomiokunta toimi kokeiluyksikkönä. Periaatteessa suunnittelu- ja käyttöönotto-organisaatio tulisi kuitenkin tehdä yksinkertaisemmaksi.

Laitteistohankintoja koskeneet neuvottelut tarjouskilpailuineen viivästyttivät käyttöönottoa lähes vuodella. Laitteet tulivat tuomiokuntaan elokuussa 1986. Tässä vaiheessa tuli vasta Teko-tekstinkäsittelyohjelmisto jo aiemmin käytössä olleen keskitetyn kiinteistötietojärjestelmän lisäksi. Näin tietojärjestelmä vaikutti 
aluksi lähinnä pöytäkirjojen kirjoittamiseen ja suoraan vain kuuden ihmisen työhön. Mikrot kytkettiin verkoksi alkuvuodesta 1987.

Suurimpaan osaan tuomiokunnan töitä ei tietojärjestelmän käyttöönotto siis aluksi juuri vaikuttanut. Toisaalta jatkossa pöytäkirjan kirjoittajien lisäksi myös muiden panosta tarvitaan erilaisissa kehittämishankkeissa. Taulukossa 1 esitellään tuomiokunnassa toteutetut ja toteutettavat tietojärjestelmät. Suurin osa järjestelmistä saadaan valmiina tai lähes valmiina. Itse kehitettäviä ohjelmia on kuitenkin paljon. Kehitystyöhön tarvitaan koko henkilöstön panosta ja aikaa. Siitä hyötyvät myös muut tuomiokunnat. Vähittäisestä käyttöönotosta saattaa kaiken kaikkiaan olla myös etua, sillä uusien asioiden oppimiseen jää näin enemmän aikaa.

Käyttöönoton organisointi projektiksi on tarkoituksenmukaista, jotta suunnittelulle saadaan tietyt viralliset puitteet ja eri henkilöstöryhmien vaikutusmahdollisuus taataan. Edustuksellinen osallistuminen ei kuitenkaan riitä. Suunnittelussa koko henkilöstöä tarvitaan erityisesti olemassa olevien töiden ja työnkulkujen kartoittamiseen ja niihin littyvien ongelmien ratkomiseen. Henkilöstön kannalta projektityössä mukanaolo merkitsee näin avautuvaa mahdollisuutta vaikuttaa kehityksen kulkuun. Mukanaolo kouluttaa muutoksen hallintaan, mutta samalla edellyttää myös koulutusta.

Suositeltava työpaikkakohtainen käyttöönotto-organisaatio voisi olla seuraava:

1) Vastuuhenkilö, joka toimii koordinoijana ja mahdollisesti myöhemmin työhönopastajana uusille tai työtään vaihtaville työntekijöille.

2) Suurilla työpaikoilla projektiryhmä, jossa on edustettuna eri henkilöstöryhmät, tehtävänään hankkeen toteuttaminen.

3) Vapaaehtoiseen osallistumiseen perustuvat, esim. työkokonaisuuksien mukaiset, ongelmakeskeiset kehittämisryhmät, joiden tehtävänä on analysoida työtehtävät, löytää ensisijaiset sovellusälueet, muotoilla uudet työkokonaisuudet sekä kehittää tarvittaessa työpaikkakohtaisia ohjelmistoja. Pienillä työpaikoilla projektiryhmä voi toimia kehittämisryhmänä.

4) Oikeusministeriöstä tai Hämeenlinnan tietojärjestelmäyksiköstä toimiva tukihenkilö tai konsultti, jonka tehtävänä on avustaa tuomiokunnan työryhmiä ja neuvoa tarvittavat tietolähteet.

\section{Annettu koulutus}

Tuomiokunnan työntekijöiden peruskoulutus oli varsin hyvä. Se antoi hyvän pohjan jatkokoulutukselle. Kehittämis- ja koulutusvaihe saatiin päätökseen yli puoli vuotta ennen ko- neiden tuloa. Koulutuksen ensimmäinen vaihe eli tietotekniikan perusteiden opetus oli käyttöönottoon nähden liian aikaisin. Tällöin koulutuksen ja käyttöönoton välinen yhteys katkesi. Toisaalta koulutusta tarvittiin aikaisessa vaiheessa kehittämisryhmien työssä. Ennen suunnitteluvaihetta työntekijät olisivat tarvinneet vielä lisää tietoja atk:sta ja toimistojärjestelmistä, jotta he olisivat todella voineet vaikuttaa ratkaisuihin.

Itse käyttöönottovaiheen opastuksessa oli puutteita. Kirjoittajat pystyivät lyhyen omatoimisen opiskelun jälkeen tuottamaan pöytäkirjoja, ja opettelu jäi tasolle, jolla tullaan toimeen. Työtä helpottaviin erikoistoimintoihin ei ehditty perehtyä, koska työt oli saatava tehdyksi.

Tässä tilanteessa oppimista olisi edistänyt huomattavasti työnopastuksen tyyppinen ohjaus sekä muutaman päivän varaaminen pelkkään harjoitteluun. Alussa olisi tarvittu kokopäivätoiminen opastaja ongelmatilanteita varten (Pirhonen 1987).

VTKK:n tekstinkäsittelykurssin opetuksessa vaikeutena oli ryhmän heterogeenisuus. Joillakin oli hankaluuksia omaksua kaikkia asioita ja suoriutua harjoittelutehtävistä, kun taas jotkut olisivat voineet perehtyä enempäänkin. Kurssilaiset jatkoivat harjoittelua koulutusmateriaalin ja Teko-käsikirjan avulla omissa työtehtävissään. Vaikka kaikki olivat jo jonkin verran perehtyneet tekstinkäsittelyyn ennen kurssia, useat olisivat halunneet koulutuksen esim. kahdessa jaksossa. Tällöin olisi välillä voinut harjoitella käytännössä, ja sitten jatkaa kurssia edelleen vaikeimpiin asioihin (Pirhonen 1987).

Tuomiokunnan tietojenkäsittelyn vastuuhenkilöllä oli oman käräjätuomarin työnsä ohella varsin laaja alue vastattavanaan. Hänen tehtäviinsä kuuluivat sekä tietojenkäsittelyn kehittämisen suunnittelu ja koordinointi että yksittäinen laite- ja ohjelmakohtainen neuvonta. Tällaiseksi käytön opastuksen vastuuhenkilöksi sopisi myös joku kansliahenkilökuntaan kuuluva, joka koulutettaisiin tehtäväänsä.

\section{Koulutuksen järjestäminen}

Tietotekniikan käyttöönotto merkitsee paitsi laitteiston ja ohjelmiston soveltamista myös työnjakoon ja organisointiin kohdistuvia haasteita sekä ennen kaikkea kehittämismahdollisuuksia. Kehittäminen paitsi edellyttää koulutusta myös avaa koulutusmahdollisuuksia. Parhaimmillaan koulutus nivoutuu yhteen käyttöönoton kanssa, niin että henkilökunta oppii ratkaistessaan eteen tulevia ongelmia. Koulutusvaatimukset ja -tavoitteet voidaan käyttöönoton etenemisen mukaan jaotella seuraavasti: 
1) Taito eritellä ja analysoida omia työtehtäviä sekä omaa työorganisaatiota, millä luodaan pohja muutoksen suunnittelulle ja kehittävälle osallistumiselle muutokseen.

2) Tietotekniikan perusteet, järjestelmien ja ohjelmistojen käyttöönotto ja erillisten ohjelmien käyttö sekä työpisteen ergonominen suunnittelu.

3) Työtehtävien sisällön ja työorganisaation sekä

4) järjestelmien ja ohjelmistojen kehittäminen.

Koulutuksen keskeisiä vaiheita ovat kehittämistyön alku ja tietojärjestelmän käyttöönotto, jotka toistuvat kehittämistyön jatkuessa. Koulutus tulisi järjestää seuraavasti:

1) Alussa tulisi perehtyä projekti- ja työryhmätyöskentelytapoihin sekä erilaisiin tapoihin tutkia työtä tavoitteena valmius ryhmätyöhön ja töiden kehittämiseen.

2) Tietotekniikan perusteiden opiskelu voitaisiin järjestää esim. luentopäivien avulla. Opintopiiritoimintaa tietotekniikan peruskysymyksistä tulisi harkita (Vehviläinen 1986). Tietojenkäsittelyn vastuuhenkilö voisi vetää opintopiiriä. Itseopiskeluun tulisi järjestää sopivia hetkiä työn lomassa. Tutustuminen johonkin käytössä olevaan järjestelmään voisi auttaa ratkaisujen ideoinnissa.

3) Käyttöönottovaiheessa tarvitaan ohjelmistoja laitteistokoulutusta. Järjestetyn opastuksen hyöty on suurempi, jos ennen kursseja tai muita koulutustilaisuuksia on ehditty hieman perehtyä järjestelmään ja laitteiden käyttöön. Koska uusia ohjelmistoja saadaan ja kehitetään jatkuvasti, oppimisvaatimukset pysyvät suurina. Jokaisen uuden ohjelman käyttöönotto edellyttää oman koulutuksensa!
4) Kurssimuotoisen opetuksen lisäksi tarvitaan käytön ohjausta itse työssä. Uusia työntekijöitä tai työtään vaihtavia työntekijöitä tulee opastaa työhönsä. Neuvonta ongelmatilanteissa on keskeistä. Tuomioistuimiin tulisi perustaa työnopastusjärjestelmä. Työnopastusjärjestelmä merkitsee työnopastajan/työnopastajien nimeämistä ja kouluttamista kussakin tuomiokunnassa. Työnopastajalle ja/tai kehittämisen vastuuhenkilölle tulisi järjestää koulutus.

\section{Lähteet}

Alioikeuksien tietojenkäsittelytyöryhmän mietintö 1984. Oikeusministeriö, tietojenjärjestelmäyksikkö, julkaisu B 25. Hämeenlinna.

Ehdotus alioikeuksien toimistoarkkitehtuuriksi 1986. Oikeusministeriö, tietojenjärjestelmäyksikkö, alioikeuksien arkkitehtuurityöryhmä, julkaisu B 26.

Huuhtanen, P., Launis, M. \& Lehtelä, J. 1983. Päätetyö. Helsinki: Työterveyslaitos.

Kallioniemi, E. 1985. Työyhteisöön tuli tietojärjestelmä. Sarja D 77. Tampere: Yhteiskuntatieteiden tutkimuslaitos.

Korvajärvi, P. \& Rantalaiho, L. 1984. Toimistoautomaatio ja toimistotyö. Sarja B 40. Tampere: Yhteiskuntatieteiden tutkimuslaitos.

Pirhonen, R. 1987. Alioikeuksien toimistojärjestelmän suunittelu ja käyttöönoton ensimmäinen vaihe Vantaan tuomiokunnassa. Valtio-opin pro gradu -tutkielma, Helsingin yliopisto.

Stenlund, H. \& Lampola, M. 1985. Tietotekniikka, hallinto ja oikeus. Jyväskylä: Suomen Lakimiesliiton Kustannus Oy.

Vantaan tuomiokunnan tietojenkäsittelyn kehittämissuunnitelma 1986. Vantaa.

Vehviläinen, M. 1986. Toimistohenkilöstö atk-opintopiirissä. Teoksessa: Rantalaiho, L. (Toim.) Toimistotyö, toimistotyöntekijät ja toimistoautomaatio ss. 162-173. Tampere: Yhteiskuntatieteiden tutkimuslaitos.

Virtanen, H. 1984. Toimistoautomaation käyttöönoton kynnyksellä. Tampere: Yhteiskuntatieteiden tutkimuslaitos. 


\section{AIKUISKASVATUS \\ The Finnish Journal of Adult Education \\ Vol. 8,3/88

Vartiainen, Matti \& Järvenpää, Eila. 1988.

Data system introduction and training; experiments at Vantaa Judicial District.

The implementation of information technology in the office environment has been one of the foremost changes to have taken place in government administration work places throughout the late 1980's. The article deals with the organization of the data system introduction and the training provided on the basis of the findings of a longitudinal study. The introduction of the data system was monitored from 1985 onwards and the study is still going on. Data was collected through observations, interviews, and questionnaires. The authors took part in providing the necessary training. The introduction phase took longer than was expected and at first information technology affected the work of only a few people. The scheduling of training turned out be a difficult matter. The central phases of training were the beginning of the development work and the actual introduction of the data system. Finally, the authors present certain recommendations regarding the organizations of introducing data systems and the content of the accompanying training. 